NASA Technical Memorandum 102741

\title{
F-106B AIRPLANE ACTIVE CONTROL LANDING GEAR DROP TEST PERFORMANCE
}

Willian E. Howell, John R. McGehee, Robert H. Daugherty, and William A. Vogler

November 1990

(NASA-IM-107741) F-1008 A IPPLANE ACTIVE CONTROL LANDING GEAR DROP TEST PERFORMANCE
(NASA) 12 P CSCL OIC

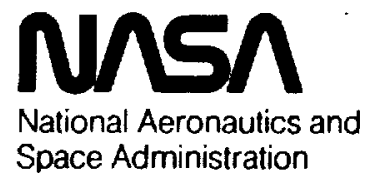

Langley Research Center Hampton, Virginia 23665 


\title{
F-106B AIRPLANE ACTIVE CONTROL LANDING GEAR DROP TEST PERFORMANCE
}

\author{
William E. Howcll, John R. McGehce, and Robert H. Daugherty \\ NASA-Langley Rescarch Center, Mail Stop 497 \\ Hampton, VA 23665
}

and

William A. Vogler, Staff Enginecr

Lockhecd Enginecring and Sciences Company

NASA-Langley Rescarch Center, Mail Stop 497

Hampton, VA 23665

\begin{abstract}
SUMMARY
Aircraft dynamic loads and vibrations resulting from landing impact and from runway and taxiway unevenness are recognized as significant factors in causing fatigue damage, dynamic stress on the airframe, crew and passenger discomfort, and reduction of the pilot's ability to control the aircraft during ground opcrations. One potential method for improving opcrational characteristics of aircraft on the ground is the application of active-control technology to the landing gears 10 reduce ground loads applicd to the airframe.

An cxperimental investigation was conducled on scrics-hydraulic active control nose gear. The experiments involved testing the gear in both passive and active control modes. Results of this investigation show that a serieshydraulic activc-control gear is feasible and that such a gear is effective in reducing the loads transmilled by the gear to the airframe during ground opcrations.
\end{abstract}

\section{INTRODUCTION}

Aircraft dynamic loads and vibrations resulting from landing impact and from runway and laxiway uncvenness are recognized as significant factors in causing faltiguc damage, dynamic stress on the airframe, crew and passenger discomfort, and reduction of the pilot's ability to control the aircraft during ground opcrations. The ground-induced structural vibrations on large, flexible airplanes can reduce the pilot's capability to control the airplanc during high-specd ground operations. These ground-induced 
dynamic loads and vibrations are magnificd for supersonic-cruise aircraft because of the increased structural flexibility inherent in these slender-body, thin-wing designs. Such operational problems with supersonic-cruise airplancs have occurred at high takc-off and landing spceds on some runways which are only marginally acceptable for most subsonic commcrcial airplanes. One potential method for improving opcrational characteristics of such airplanes on the ground is the application of active-control technology to the landing gears to reduce the ground loads applied to the airframe.

Previous analytical studies (references 1 and 2) have been conducted to determine the feasibility and potential benefits of applying active load control to the airplane main landing gear to limit the ground loads applicd to the airframe. The results reported in reference 2 indicate that a shock strut incorporating a hydraulically controlled actuator in scrics with the passive elcments of a conventional shock strut have acceptable propertics and would be quite feasible to implement. Based on the results of reference 2, a modificd version of the serics-hydraulic active gear which climinated the actuator and effected control by using a scrvovalve to remove or add hydraulic fluid to the shock-strut piston (lower cylinder) was analytically and experimentally investigated in references 3 through 6 . Based on the results described in these references, the gear from a F-106B was modificd for drop tests. The purpose of this paper is to present the results of passive and active drop tests of the F-106B nose gear.

\section{SERIES-HYDRAULIC ACTIVE-CONTROL GEAR}

\section{Control Concept}

The scrics-hydraulic control concept limits the gear force applicd to the airframe by regulating the damping force (hydraulic pressurc) in the piston of the olco-pncumatic shock strut. To incorporatc this active control concept into a conventional gear requires a modification to the gear to control the flow of fluid in or out of the shock-strut with a scrvovalve. A schematic drawing of a series-hydraulic landing gear that has becn fabricated to permit cxperimental verification of the concept is shown in figurc 1 . The gear represented is a simple gencric olco-pncumatic shock strut without a metering pin. The control concept is designated scrics-hydraulic becausc the control 
scrvovalve is in series with the shock-strut piston and hydraulic fluid is removed from or added to the piston to provide force regulation.

The actual gear sclected for inclusion of the active control concept was the nose gear of the F-106B with no metcring pin. The gear was modified to accommodate the control by adding a threc-tubc arrangement to the orifice as shown in figure 2. A collection chamber at the top of the 3 tubes connects the fluid in the shock-strut piston to one side of the secondary piston. The other side of the secondary piston is connected to the servovalve. The purpose of the secondary piston is to mechanically limit the amount of fluid that can be taken out or added to the shock strut for flight safety.

The control hardware required for the active gear lest program included a $200 \mathrm{GPM}\left(0.76 \mathrm{~m}^{3} / \mathrm{min}\right)$ servovalve, a low-pressure (atmospheric) rescrvoir, a 9 GPM $\left(0.04 \mathrm{~m}^{3} / \mathrm{min}\right)$ hydraulic pump, a high-pressurc (3000 psi (20.7 MPa)) accumulator, an clectronic controller, and feedback transducers. The isolation valve allowed isolation of the gear from the control hardware to permit passive gear testing.

\section{System Opcration}

System opcration is bricfly described as follows. The clectronic controller detcrmines the opcrational mode (take-off or landing), and implements the control laws. The control laws programmed into the controller are based on the following logic. At touchdown, the controller reccives a signal from a transducer to measure the instantancous sink rate. Assuming a constant mass, the present energy is then calculated. An integration of the accelcration is also begun at this time so that the gear upper mass velocity is known at all subsequent times. As the gear compresses, the remaining work capability of the shock strut is calculated using the instantancous values of acceleration (or force) and stroke remaining. This remaining work capability is then compared with the present energy of the upper mass calculated using the instantancous upper mass velocity. When the remaining work capability equals or excecds the present encrgy of the upper mass the controller stores in memory the instantancous valuc of the scalcd accelcration (wing-gear interface force) for use as the impact limit force and activates the servovalve control loop. The controller attempts to maintain this force by removal or addition of hydraulic fluid from or to the olco-pncumatic shock strut lower 
chamber. Fecdback from the accelerometer provides the controller with a means of determining the difference between the present and the desired force. The slope of the accelcrometcr output is also used for ratc fecdback in the control laws, so that if the force is not at the proper level but is tending to return to it on its own, the magnitude of the scrvo command would be reduced by some amount. Likewise, force trends away from the desired level provoke servo commands larger than would be generated if using force difference alone in the control laws. When the upper mass encrgy has been dissipated and the sink velocity is nearly zcro, the controller linearly transitions the impact limit force to a value of zero for rollout control. During rollout and taxi the controller maintains the wing-gear interface force within a designed tolerance (deadband of $\pm 1750 \mathrm{lbf}( \pm 7.8 \mathrm{kN})$ for these tests) about the static normal force. After control initiation at touchdown, the controller continuously operates with a long-time constant (5 scconds) control to return the gear stroke to the designed static equilibrium position.

\section{EXPERIMENTAL INVESTIGATION}

Landing simulation tests (passive and active) with the nose gear from a F-106B fighter interceptor airplane (fig. 3) were conducted at the NASA Langley Rescarch Center to demonstrate the feasibility and the potential of the active gear for reducing ground loads transmitted to the airframe. The vertical drop tests simulated touchdown impact with and without lift.

\section{Drop Tests}

A photograph of the lest apparatus for conducling the vertical drop tests of the nose gear is shown in figure 4. Additional details of the gear and apparatus are shown in figure 5 . Using the drop test apparatus, the nose gear was dropped vertically with simulated lift at $4.5 \mathrm{fps}(1.37 \mathrm{~m} / \mathrm{s})$ in both the passive and active modes. A $1-g$ lift simulation was obtained by using crushable aluminum honcycomb to siop the drop carriagc (upper mass) vertical acceleration. The chosen test condition is representative of the airplanc being derotated at a high pitch ratc. A sccond test of the gear was also conducted at a vertical specd of $2.5 \mathrm{fps}(0.76 \mathrm{~m} / \mathrm{s})$ without lift. Without lift applicd, vertical specds higher than about 2.5 fps $(0.76 \mathrm{~m} / \mathrm{s})$ would causc the 
gear 10 bottom out. Such a drop tcst is representalive of losing pitch control during derotation.

A comparison of the measured upper mass accelcration for the active versus passive gear without lift is shown in figure 6 . Significant cvents such as drop carriagc release, frec fall, tirc impact, and control activation are indicated in the figurc. A $47 \%$ decreasc in upper mass accelcration was obtained with the active control gear. The decrease in accelcration translates to a $47 \%$ decrease in the amplitude of forces transnitted to the airframe. For the $2.5 \mathrm{fps}(0.76 \mathrm{~m} / \mathrm{s})$ vertical drop without lift, the passive gear stroke shown in figure 7 nearly bottomed out; conscqucntly, the active gear siroke was essentially the same as for the passive gear case. Upper mass acceleration data for a $4.5 \mathrm{fps}(1.37 \mathrm{~m} / \mathrm{s})$ drop with lift are shown in figure 8 . A $36 \%$ decrease in the transmitted force was obtained with the active gear. As shown in figure 9, there was a $10 \%$ increase in the strut stroke associated with the active control.

\section{CONCLUDING REMARKS}

A potential method for improving the operational characteristics of aircraft on the ground by the application of active-control technology to the landing gears to reducc ground loads applicd to the airframe has becn investigated. An experimental program was conducted on a series-hydraulic active-control nose landing gear from a F-106B fighter interceptor aircraft involving both passive and aclive control modes. Results of the investigation show: (a) That such a concept can be achicved llurough modificalion of cxisting hardwarc, and (b) that the concept is cfreclive in significantly reducing the loads transmitted by the gear to the airframe during landing and ground opcrations. 


\section{REFERENCES}

1. Wignot, Jack E.; Durup, Paul C.; and Gamon, Max A.: Design Formulation and Analysis of an Aclive Landing Gcar. Volume I, Analysis. AFFDL-TR 71-80, Vol. I, U.S. Air Force, August 1971. (Available from DDC as AD 887 127L.)

2. Bender E. K.; Berkman, E. F.; and Bicber, M.: A Feasibility Study of Aclive Landing Gear. AFFDL-TR-70-126, Air Force, July 1971. (Available from $\mathrm{DDC}$ as AD 887 451L.)

3. McGehec, John R.; and Dreher, Robcrt C.: Expcrimental Investigation of Active Loads Control for Aircraft Landing Gear. NASA TP-2042, 1982.

4. Morris, David L.: Active Landing Gear Responsc Testing. ADWAL-TM82-177-FIEM, U.S. Air Force, April 1982.

5. McGchce, John R.; and Morris, David L.: active Control Landing Gcar for Ground Load Allcviation. AGARD-CP-384, pp. 18-1 through 18-12, March 1985.

6. Morris, David 1.: F-4 Active Control Landing Gear Dynamic Response Tcsting. AFWAL-TR-85-3005, Air Force, August 1985. (Available from DDC as AD-B096481L.)

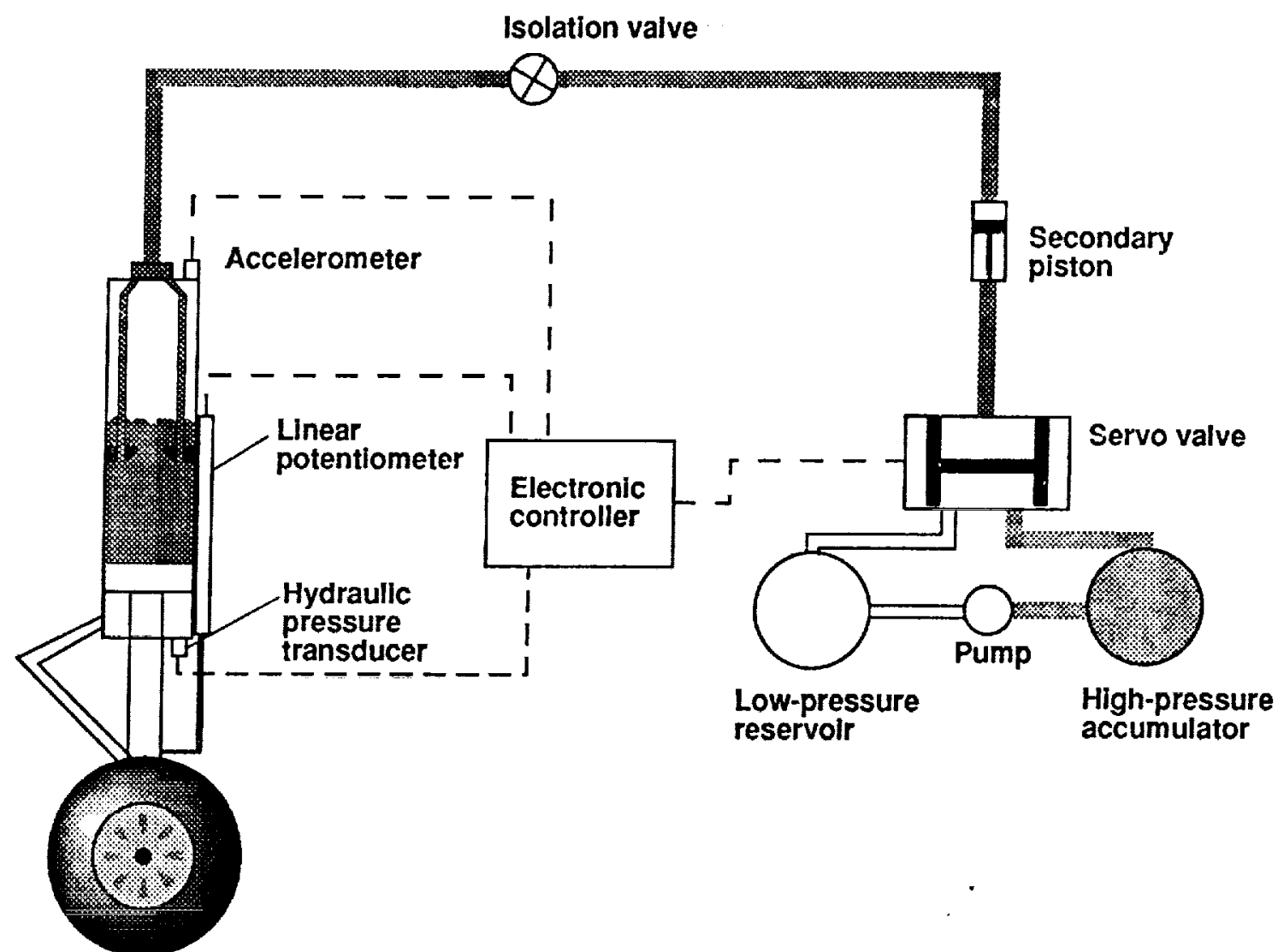

Figure 1.- Schematic of series-hydraulic active control landing gear. 


\section{ORIGINAL PAGE \\ BLACK AND WHITE PHOTOGRAPH}

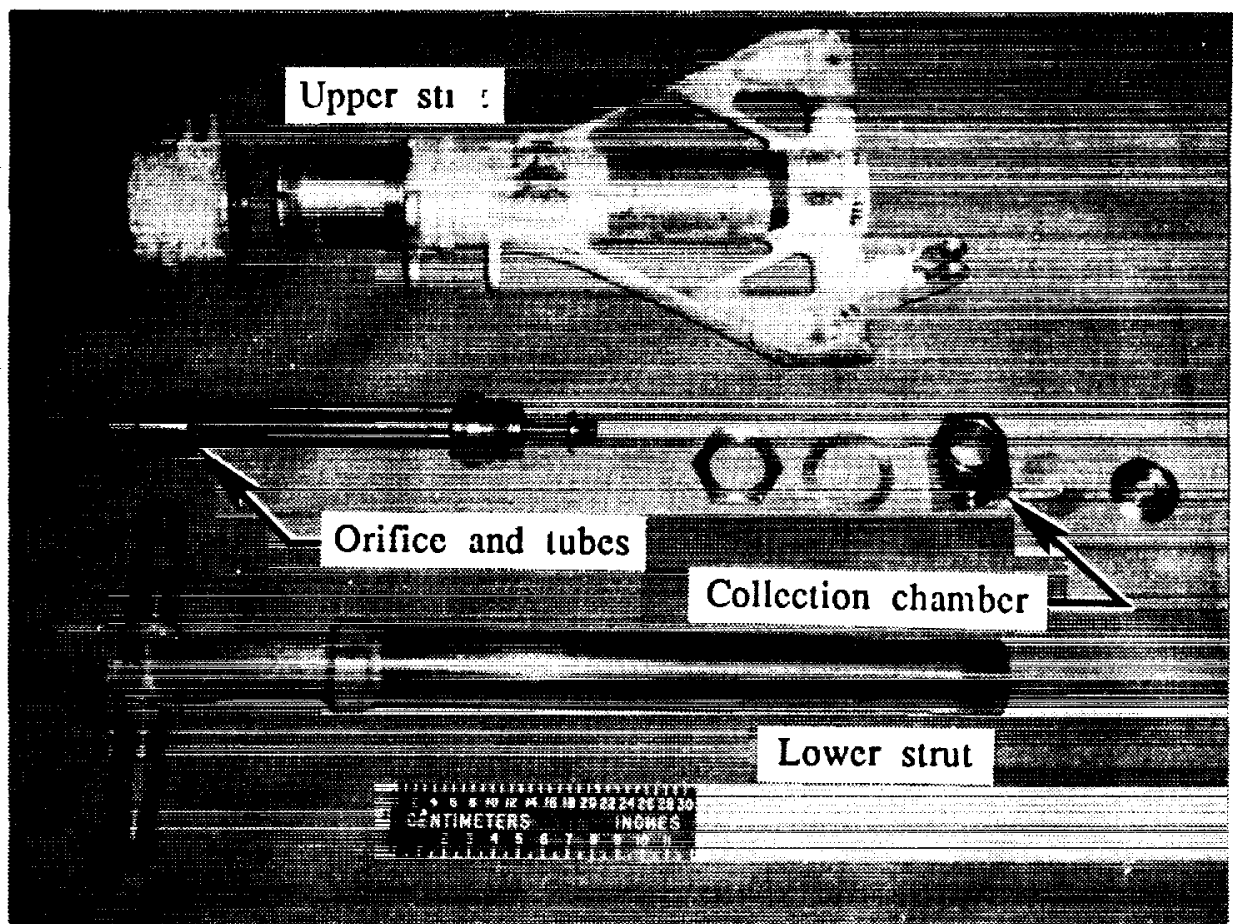

Figure 2.- Disassembled, modified F-106B nose gear.

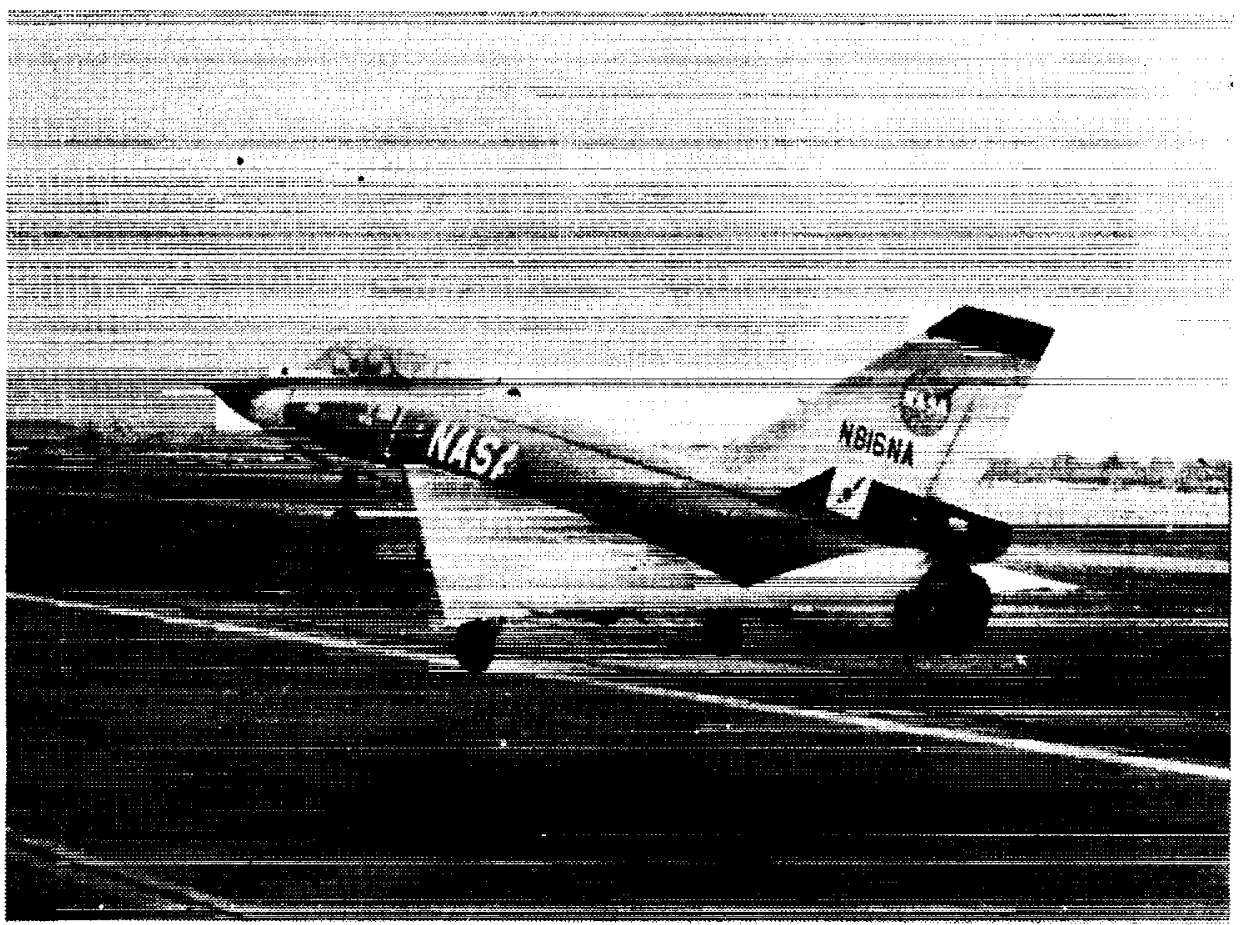

Figurc 3.- F-106B fighter interceptor airplane. 


\section{ORTGINAL PAGE \\ BLACK AND WHITE PHOTOGRAPH}

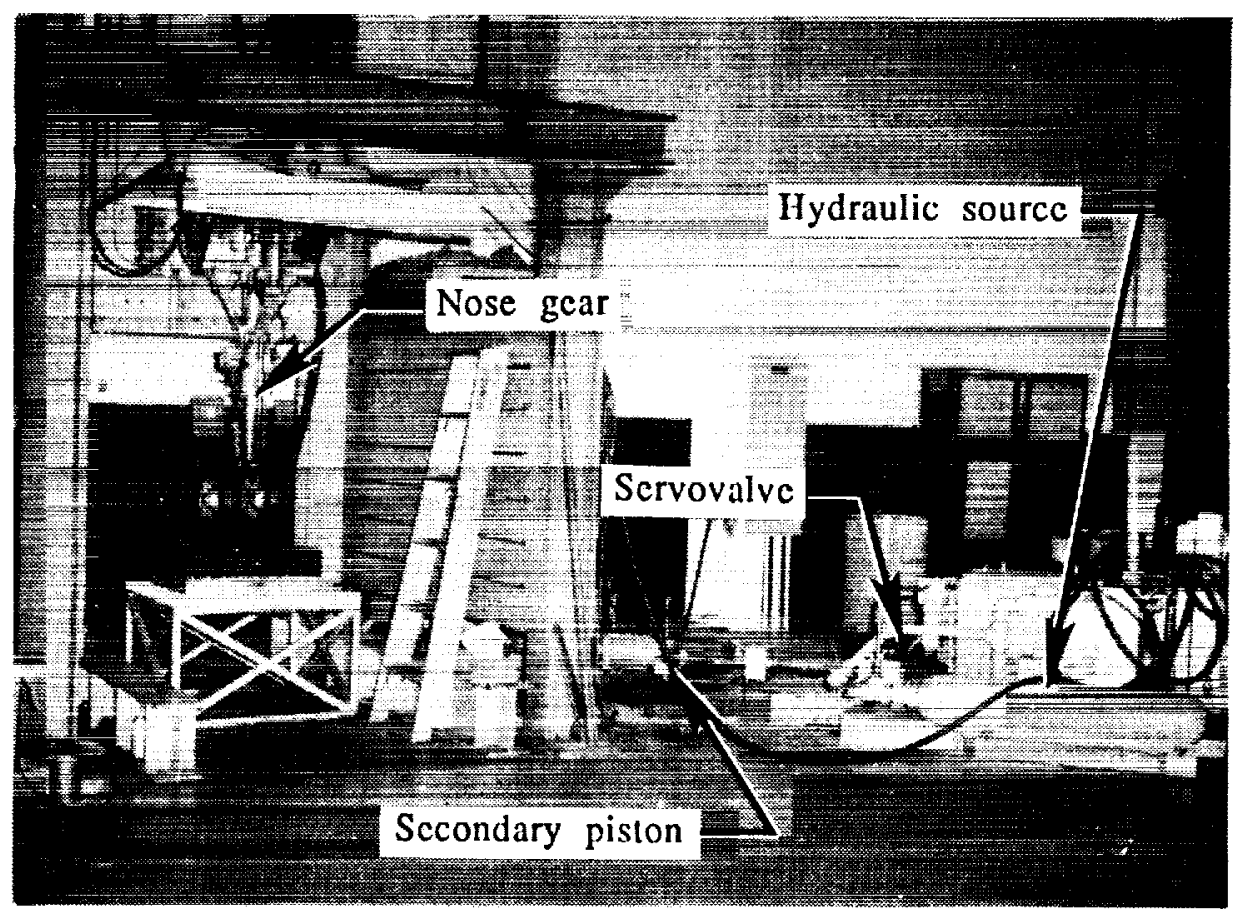

Figure 4.- Nose gear drop lest apparatus.

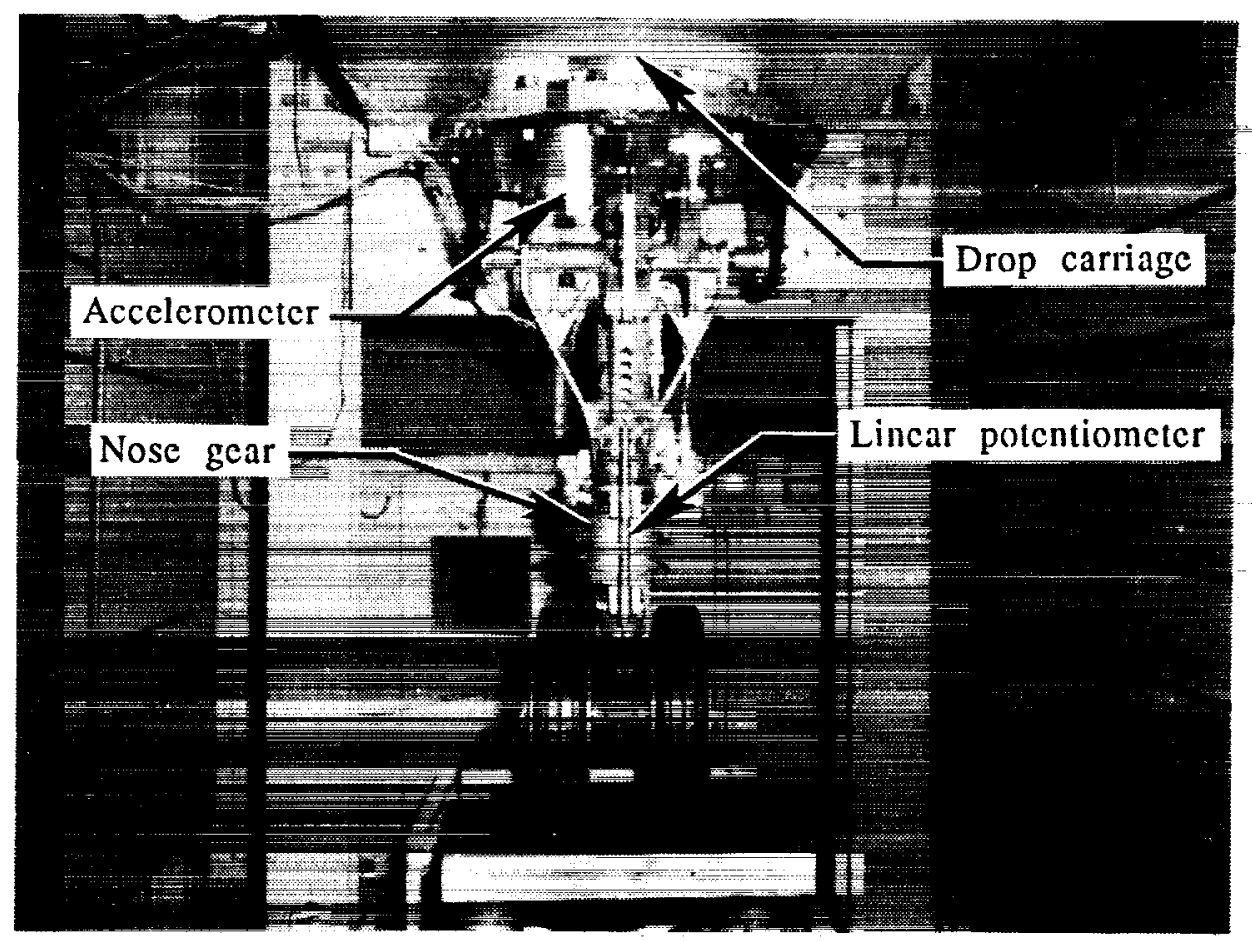

Figure 5.- Nose gear mounted on drop carriage. 


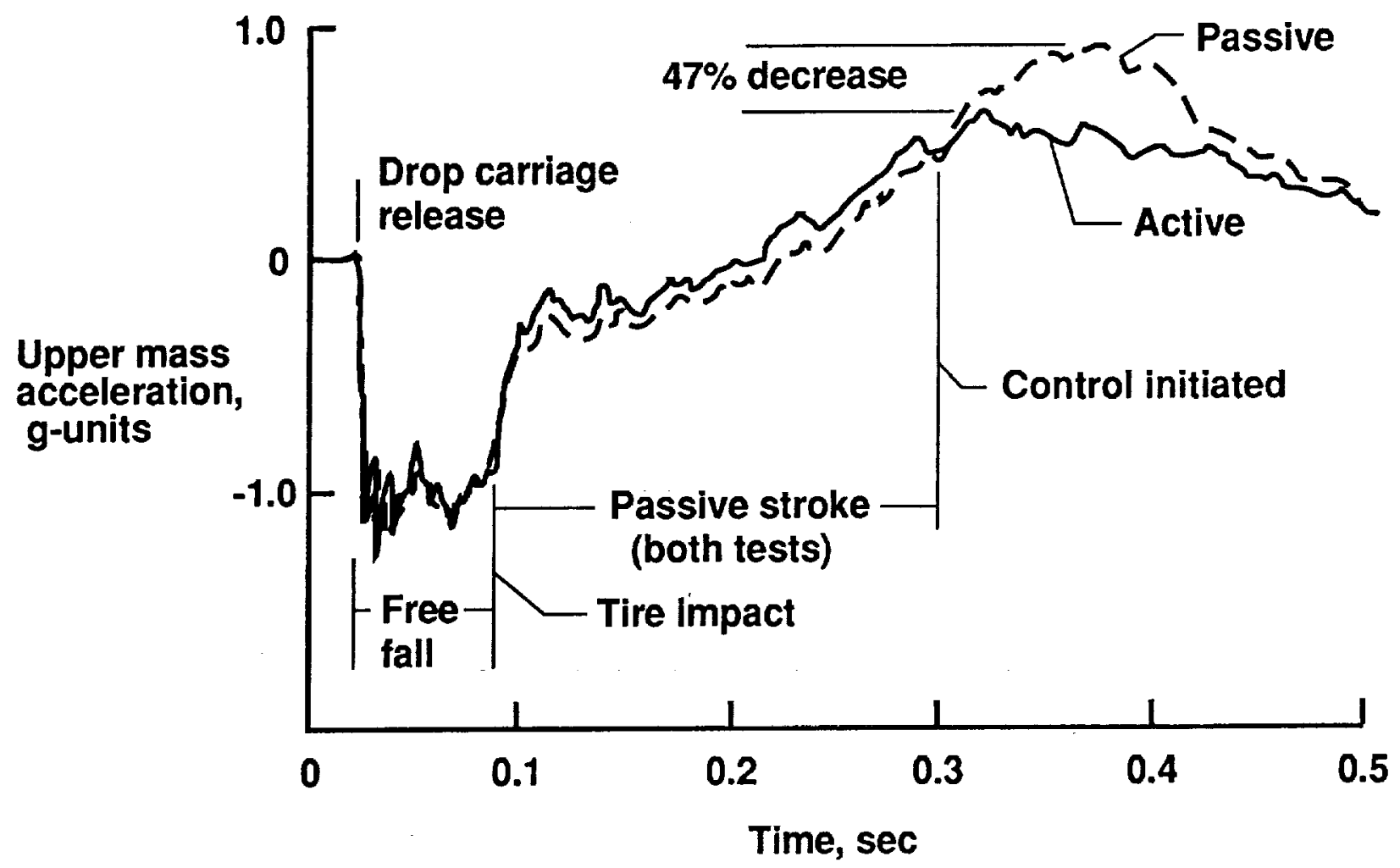

Figure 6.- Comparison of passive and aclive control accclcrations for vertical drop of nose gear at $2.5 \mathrm{ft} / \mathrm{sec}(0.76 \mathrm{~m} / \mathrm{sec})$ without lift.

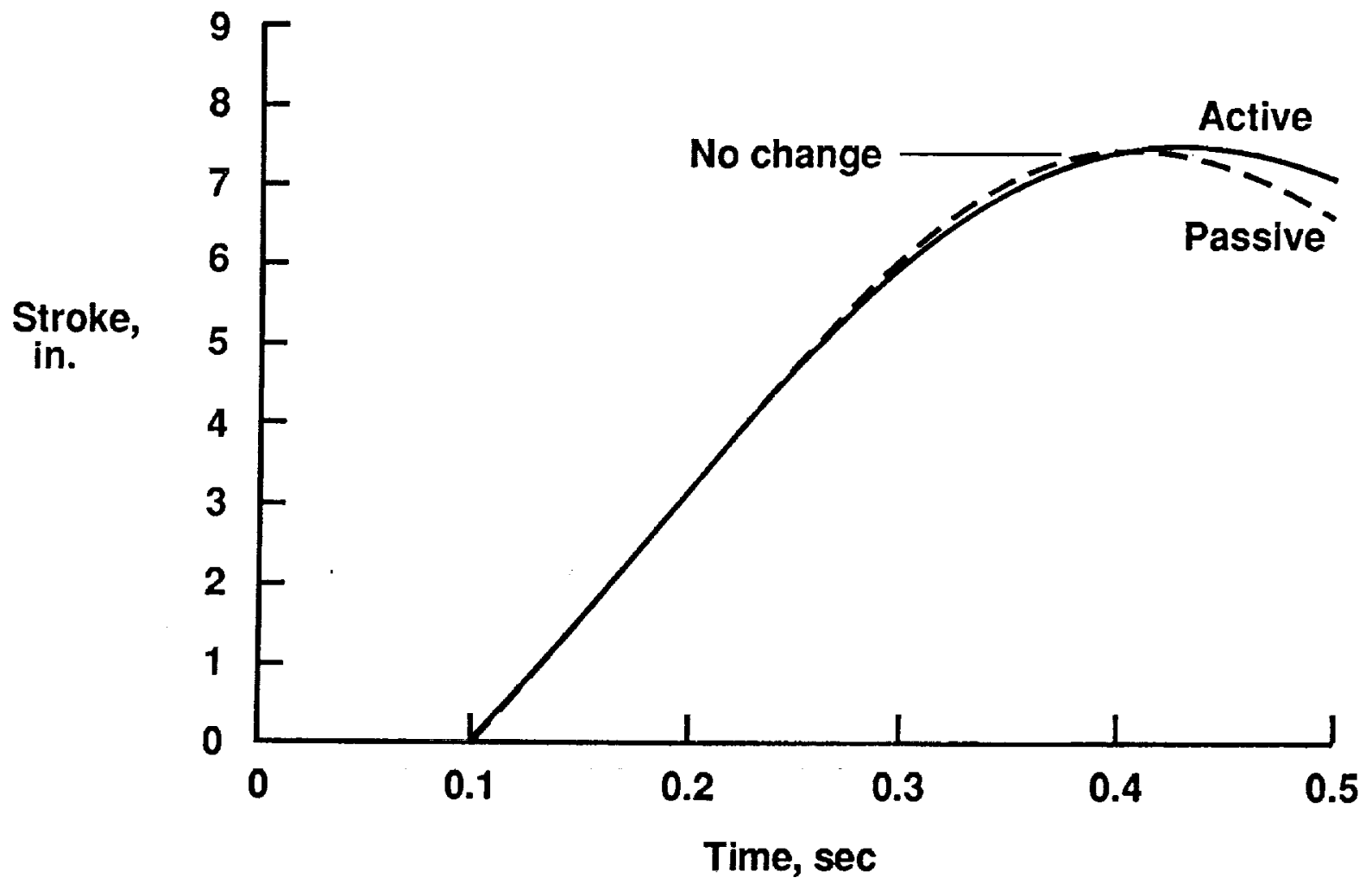

Figure 7.- Comparison of passive and aclive control strut stroke for vertical drop of nose gear at $2.5 \mathrm{ft} / \mathrm{sec}(0.76 \mathrm{~m} / \mathrm{sec})$ without lift. 


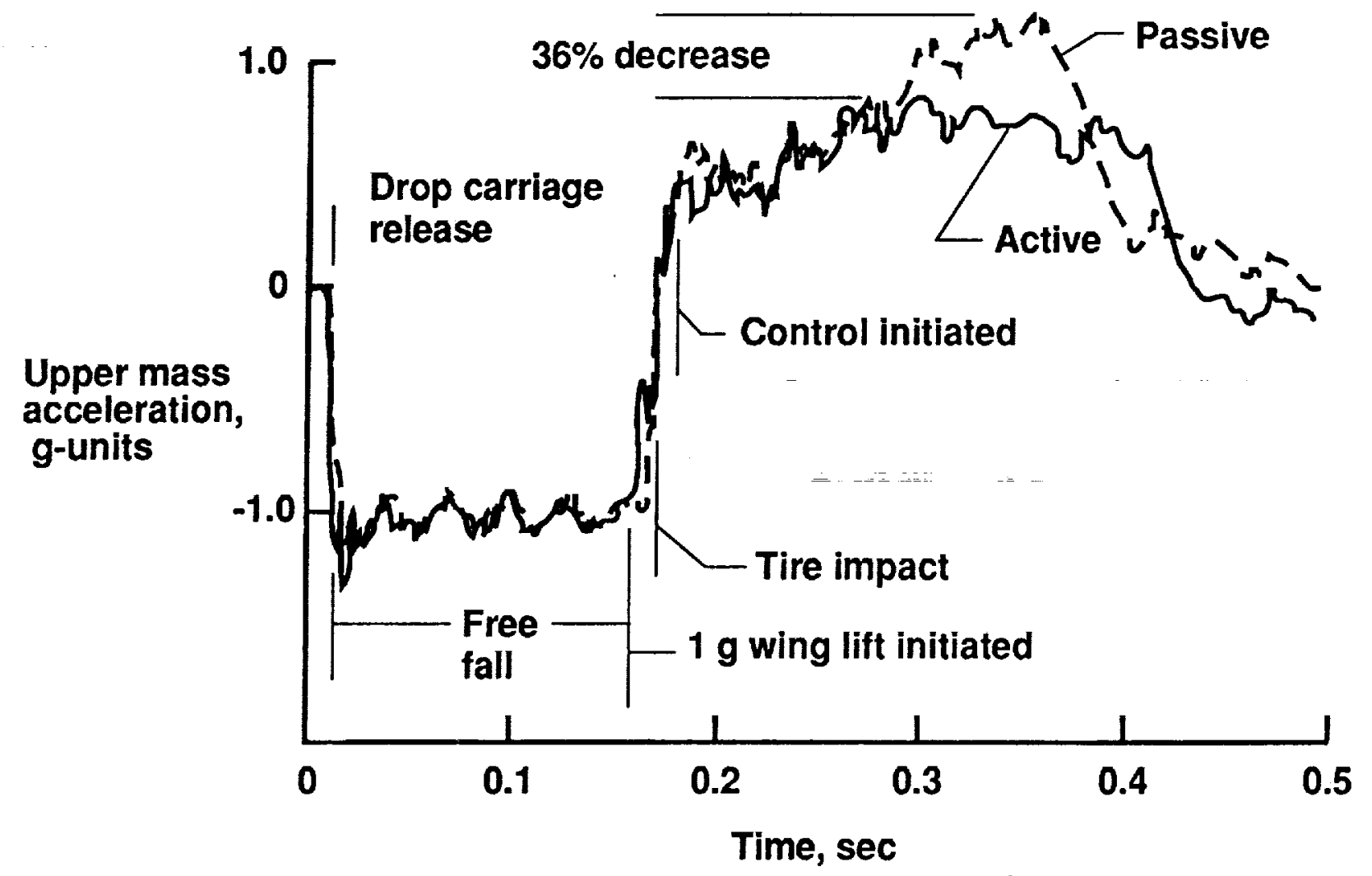

Figure 8.- Comparison of passive and active control accelerations for vertical drop of nosc gear at $4.5 \mathrm{ft} / \mathrm{scc}(1.37 \mathrm{~m} / \mathrm{sec})$ with lift.

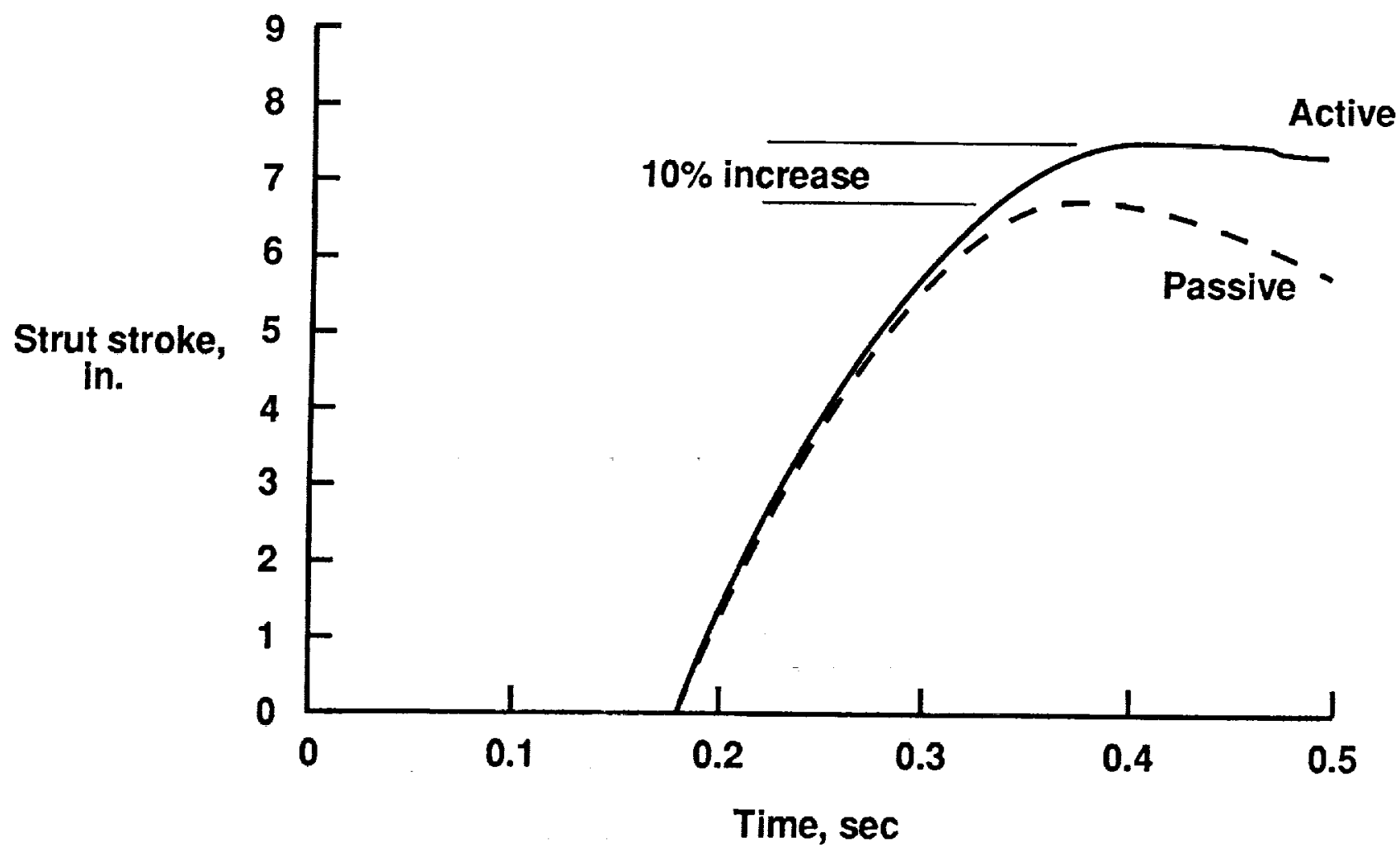

Figure 9.- Comparison of passive and active control strut stroke for vertical drop of nose gear at $4.5 \mathrm{f} / \mathrm{scc}(1.37 \mathrm{~m} / \mathrm{scc})$ sith lift. 


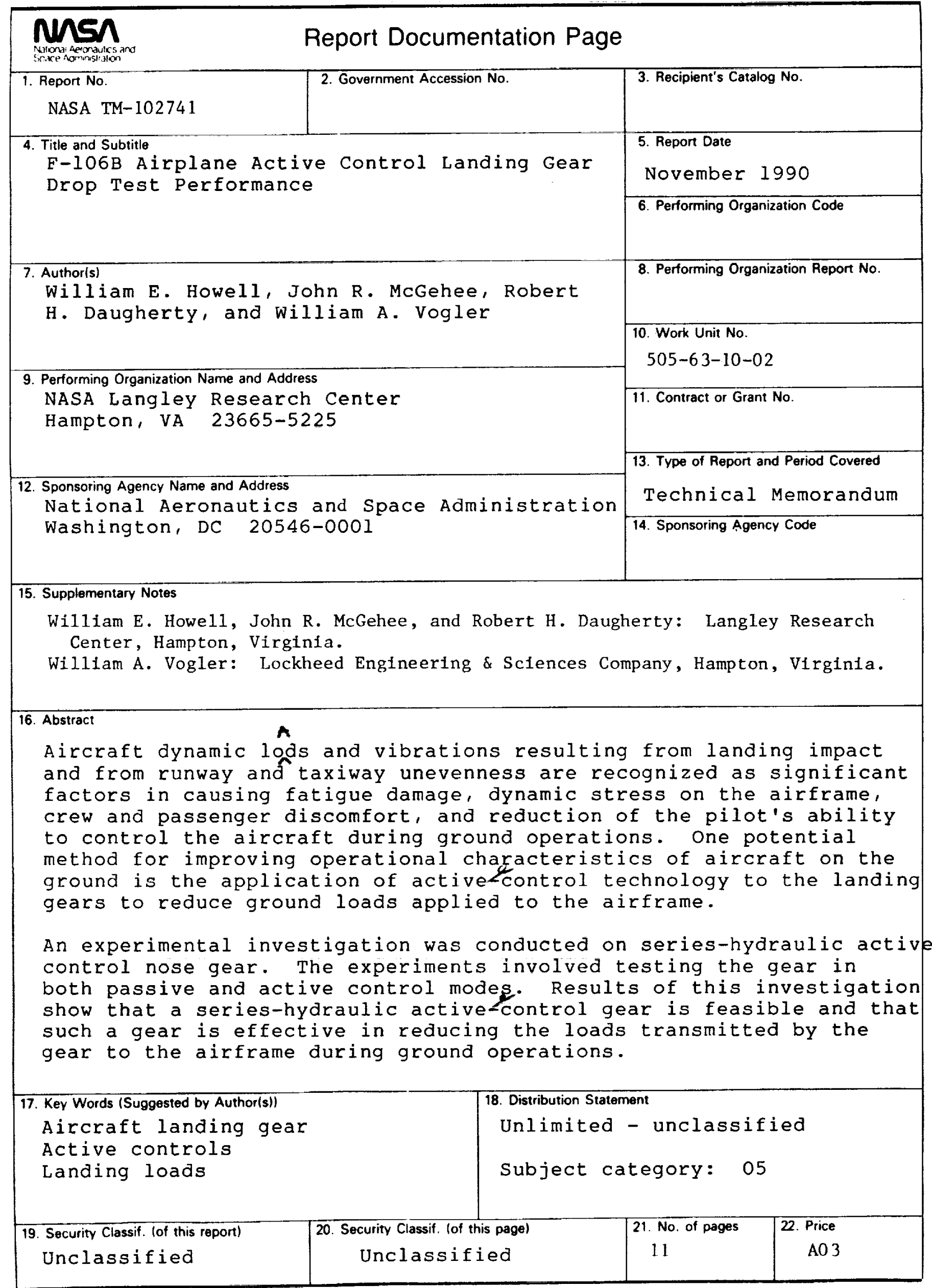

